\title{
THE IMAGE OF THE BIRD ON THE TREE OF LIFE - SYMBOLISM AND BELIEFS 1
}

\author{
Elena Panayotova \\ elena.panajotova@gmail.com
}

Faculty of Educational Studies and Arts, Sofia University "St. Kliment Ohridski", Bulgaria

Abstract: The presence of the bird of the Tree of Life in arts and crafts has been reviewed. The number of birds according to different beliefs has been analyzed. The symbolism of the different bird species is discussed. The topic was proposed for development in high school visual arts and computer graphics. Some student works are shown.

Keywords: Bird of the Tree of Life; Symbol of the Bird; Tree of Life; Fine Arts; Computer Graphics

\section{ОБРАЗЪТ НА ПТИЦАТА НА АЪРВОТО НА ЖИВОТА - СИМВОАИКА И ВЯРВАНИЯ2}

\section{Е^ена Панайотова}

Факултет „Науки за образованието и изкуствата“" при Софрийски университет "Св. КАимент ОхриАски", Бьлгария

Резюме: Направен е преглед на присьствието на птицата на Аьрвото на живота в произведения на изкуствата и занаятите. Анализиран е броя на птиците спореА различни вярвания. Разгледана е символиката на различните вилове птици. Темата е прелложена за разработване в часовете по изобразително изкуство и компютърна графика в средното учимище. Показани са някои ученически творби.

КАючови Ауми: Птица на Аьрвото на Живота; символ на птицата; Аърво на живота; изобразително изкуство; компютьрна графика

В световното културно наслеАство се наблюдава сериозно присьствие на образа на Аьрвото на живота, изобразявано като Аьрво и^и голямо стилизирано цвете, в клоните на което често присъстват стилизирани образи на птици - символ на сговор и приятелство,

\footnotetext{
1 The article presents results from a paper, presented at LCH 2019 conference

${ }^{2}$ Статията преАставя и резултати от АОКАаА, изнесен на конореренция $\underline{\mathrm{LCH}} 2019$
} 
крехкост и прехолност на всичко земно, на връзката межАу земния И небесния свят. Образьт на Аървото на живота въАнува човешката мисъ^ от Аревни времена. Хората приписвали чудодейни свойства на Аьрвото от него черпели сила и мощ, прегръщали го за зАраве, вземали клонки и ги носели за късмет. Постепенно сътворили и написали вълшебни приказки, в които одухотворили образа на Аьрвото. Проп вижАа причините за приказните трансорормации в различни явления - митове и легенАи, религии и култове, Животьт на хората и този в природата. Той прослеАява връзката на приказката с религията. Енгелс казва, че „всяка религия не е нищо Аруго, освен франтастично отражение в главите на хората на външни сили ... - отражение, в което земните сили вземат фоормата на неземни" (Engels, 1978: р. 324). Наблюдаваните процеси и явления приАобиват религиозни и фантастични фрорми и приказни сюжети. „В началните сталии на историята на такова отражение най-напрел се полАагат природните сили" (Prop, 1995: р. 27). Природните сили са почитани, омилостявани. Във въображението на хората трайно се настанили образи като: вьлшебна гора, вьлшебно Аърво, Аьрво, Ааряващо различна благолат, свьрзващо горния и Аолния свят. Аьрветата приютяват в клоните си различни герои, помагат им в битки. Аървото е и Пьт, и стьлба - към по-висши светове. По пьтя от Аървото към небето често участва и птицата - като посреАник МежАу най-високите кАОни и върха на Аьрвото, и небето. В клоните на приказните, митични образи на Аьрвото на живота наблюдаваме различен брой птици - „ґъльби, орли, абстрактни птици с неопределена порода" (Tsutsiev, 2015: p. 66).

Аървото на живота е изобразявано основно по Ава начина - с прототип Аърво от природата или с прототип ваза или Аруг СъА С цветя и^и кАонки. Първият начин - Аърво на живота (Световно, Космическо Аьрво, центьр на Земята) с прототип на образа дьрво с ясно изразена корона, ствол и мощна коренова система, е характерен за Аревна Индия, Иран, Асирия, Месопотамия, Скандинавия, Австралия, Китай и Ар. Птиците се изобразяват кацнали по клоните на Аьрвото на живота.

Вторият начин е характерен за християнската тралиция. Тук визуален израз на Аьрвото на живота е разклонено кичесто цвете или кАОнки, поставени в сьА - саксия, ваза или чаша. "Този сьА е чаша за 
евхаристия, предназначен за най-великото християнско тайнство причастието... Централният елемент поллежи на композиционно изменение... и Аори само няколко стрька от ^оза или друго растение, и^И части от тях - КАОН, цвят, пАОА - СИмволизират Аьрвото на живота в християнството" (Tsutsiev, 2015: рр. 52-67). В България, Русия и Гърция така описания визуален символ е много разпространен - в стенописи, текстил, керамика, металопластика, Аьрворезба, каменни реледри, и^юстрации на цьрковна Аитература и Ар. В България тази композиция като стенопис има име - Алафранга, която е изпьлнявана в цьрковната и частна архитектура през ВъзражАането. В тази композиция Аьрвото на живота е изобразявано като силно стилизирано растение, на найгорните к^они на което често са изобразявани птици. Те са кацнали върху клонките или цветовете и межАу тях обикновено има кичесто цвете или узрял плоА. Птиците са били считани от еАна страна на разбирателството в Аома (птиците са обърнати еАна към Аруга - в знак на сговор и съгласие). От Аруга страна, птиците не случайно са на найвисоките клони - от там те осъществяват връзката межАу земния и небесния свят, между битието и висшите сили. Вярвало се е и че птиците, билейки на по-високо, са посреАник за сбълване на мечтите и осъществяване на желания. Птицата е помагала да бъдат чути молитвите, пренасяла ги е в по-висшите нива и по този начин е помагала за здравето и благоденствието на хората. На някои места крилете на птиците са изобразявани като ангелски крила, а около главите им са изобразявани ореоли. Народьт е съзАал с безкрайното си въображение образи от растителен и животински свят, които е вярвал, че му помагат. Затова Алафррангата е изографисвана с много

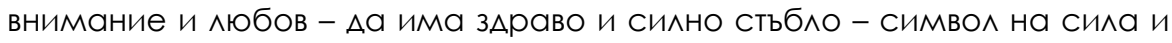
изАьржливост на хората в къщата, цветовете й били с искрящи и ярки цветове - като светлите и Аобри събития в Аома, птиците по клончетата Аобри помощници и споАвижници Към висшите сили.

Интересно е, че в християнския вариант на изобразяване на Аьрвото на живота животинският свят е преАставен само от птици. Отсъстват грифоонте и копитните животни $А$ ство^а, както и влечугите и змиите в корените на дьрвото. Присьствието на чашата за евхаристия 
означава, че слеА „най-великото християнско тайнство - причастието“ (Tsutsiev, 2015: р. 67) Аървото изразява живота в неговата най-позитивна страна, свьрзана с Ауховното израстване и по-близо мо Божествения смисъл на живота. Следователно, не са необхолими пазителите грифони и копитни, които присьстват Ао Аьрвото на живота в нехристиянските му визуални варианти. Същото се отнася и $А$ о влечугите и змиите в корените, които обитават "Аолния свят", свьрзван с отрицателната, не Ауховно извисена страна живота. В Светото писание Сатаната постоянно е оприличаван на змия или на змей, Аракон, който е орантастична форма на змията" (Prior, 1993: р. 60). Броят на птиците в различните образи на Аьрвото на живота е различен - в зависимост от наратива, с който той е натоварен.
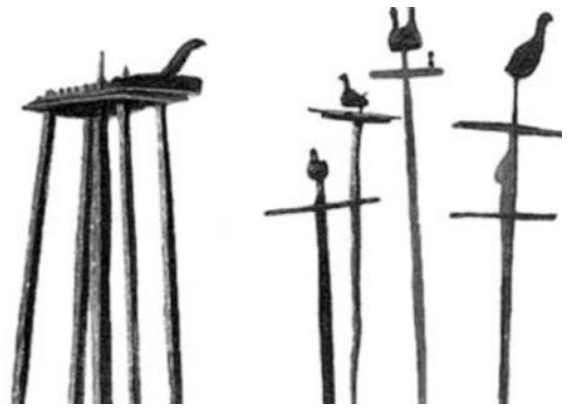

Фиг.1. Шаманско Аърво с орел на Bъpхa (Tokarev, 1980: p. 331)

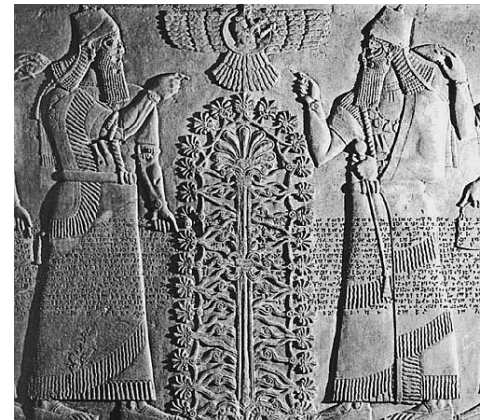

Фиг.2. Цар Ашшурнасирпал II и Крилатият Бог, покланящи се на свещеното Аърво

(Гипсов реледр от Асирия, 9в.пр.н.е, АонАОН, Британски музей)

Когато птицата на Аьрвото е еАна, тя е преди всичко символ на Извисяване и път КъМ по-висши светове, КъМ по-високо ниво на Ауховност. В световната Аитература героят има възможност $А$ व Стигне $\Delta$ о небето - чрез дьрвото и птицата, която поема щафетата от вьрха нагоре. Проп разглежАа „мотивьт за дьрвото, по което героят стига на небето... Приказката отразява широко разпространената представа, че Авата свята са съелинени от елно Аьрво. ... Представата за дьрвотопосредник е свързан и с представата за птицата... Всеки шаман си има 
шаманско Аьрво, т.е. висок прьт с напречни прьчки, наподобяващ стьлба, на върха му е изобразен орел. Това Аьрво е свьрзано с посвещаването в шаманство." (Prop, 1995: р. 207).

В шумерската и Аруги традиции ритуално се почита Аьрвото на живота, на върха на което има птица.

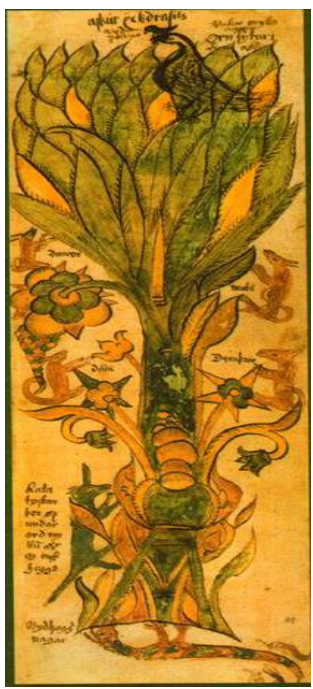

Фиг.3. Топаров, Световното Аърво - универсални знакови комплекси
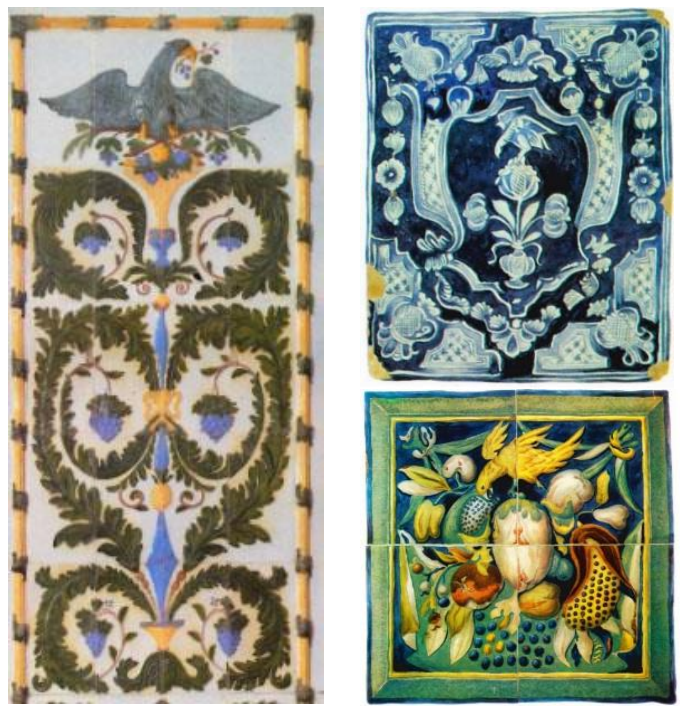

Фиг.4. Маслих.

Русско керамично изкуство
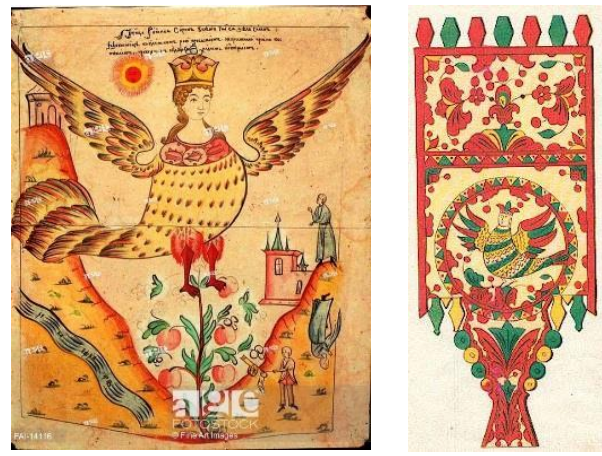

Фиг. 5. Библейски птици - стенописи от Северна Осетия 

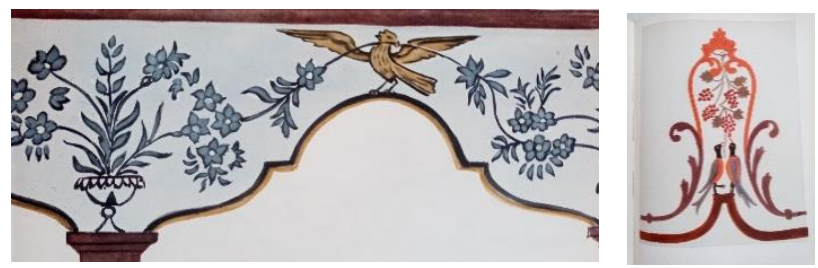

Фиг. 6. Стенописи в Рилския манастир

Птицата на върха на Аьрвото на живота е символ на врьзката межАу земния и небесния свят, затова и с нея контактуват царе и богове. Тя е пьт към тайнства и източник на нови възможности. Често птицата на Аьрвото е орел - символ на неограничени сили и възможности. Найразпространена е визуалната концепция на Аве птици на Аьрвото на живота. Когато те са обърнати енна към Аруга, символизират сговор, ^юбов, приятелство, съзидание и взаимопомощ, стремеж към развитие в бъдеще. В българското стенописно изкуство се среща Аьрвото на живота във Възрожленската Алафрранга.

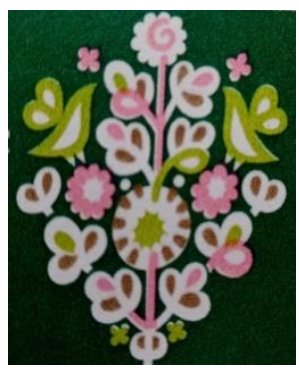

Фиг.7. Аървото на живота, Стефан Кънче

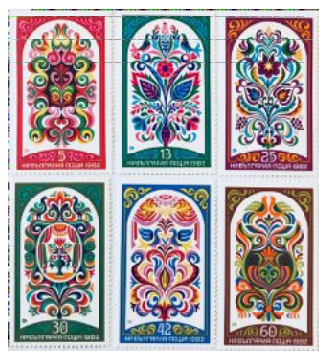

Фиг.8. Серия пощенски марки "Алафранга“, Стефан Кънчев

„Аве птици на Аьрвото на живота, обърнати еАна кьм Аруга, са познати в културата на скити и гърци, в руското и източно изкуство. Аьрвото на живота - извор на живот, заеАно с Авете птици - п^одородие и вечен живот“ (Kuzmina, 1976: р. 56) „Растетие, устремено нагоре, сьс симетрични миста, цветя и плодове и заАьлжително - симетрично разположени еАна към Аруга Аве птици по клоните" носи семантиката на жизнена сила и нейното проявление и развитие (Machinsky, 1978: p. 133). Често в руското изкуство Авете птици се изобразяват като „птици на ягоАово Аьрво“ или "петлета при бреза" - като Аобавен символен смись^ за „сладьк живот" (Maslova, 1978: р. 178). 

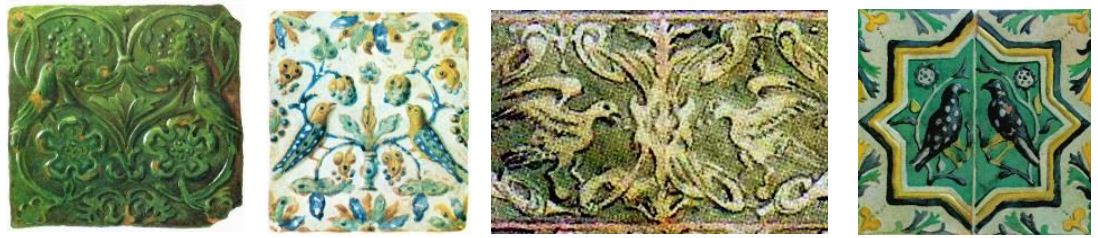

Фиг.9. Маслих. Руско керамично изкуство
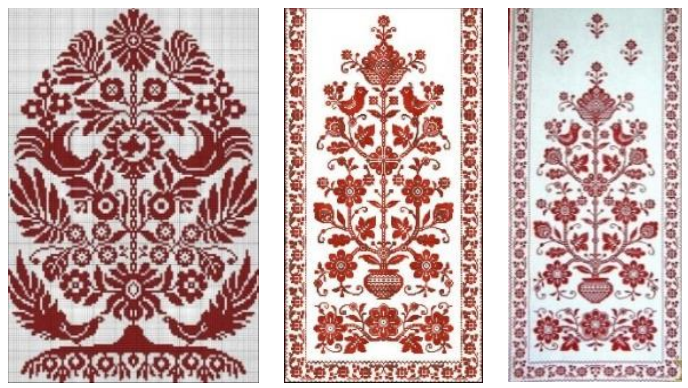

Фиг. 10. Руски мотиви за бродерия

Ангелика Хайнрих (Heinrich, 1995: р. 243) стига Ао извола, че "Аьрво с Аве птици, къ^вящи от плодовете на Аьрвото е мотив, заимстван от иранското изкуство, който на много места се разглежАа като християнски", тъй като той е навлязъл в предхристиянската култура и е развит по време на християнството. Когато Авете птици са поставени на различни нива - това е символ на развитие на еАната с помощта на Аругата, т.е. напомня за духовния ангажимент на всеки да полкрепя и насьрчава развитието на другия.
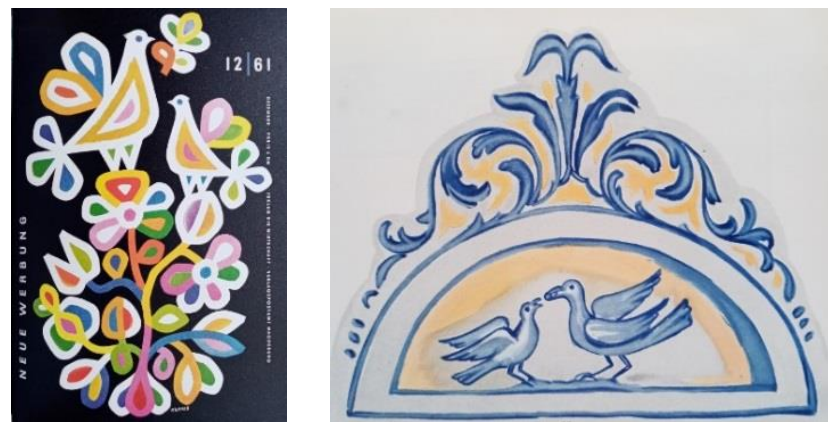

Фиг. 11. Проект на пощенска марка, Стефан Кънчев

Фиг. 12. Стенопис от Ри^оманастирския метох „Ор^ица“ 

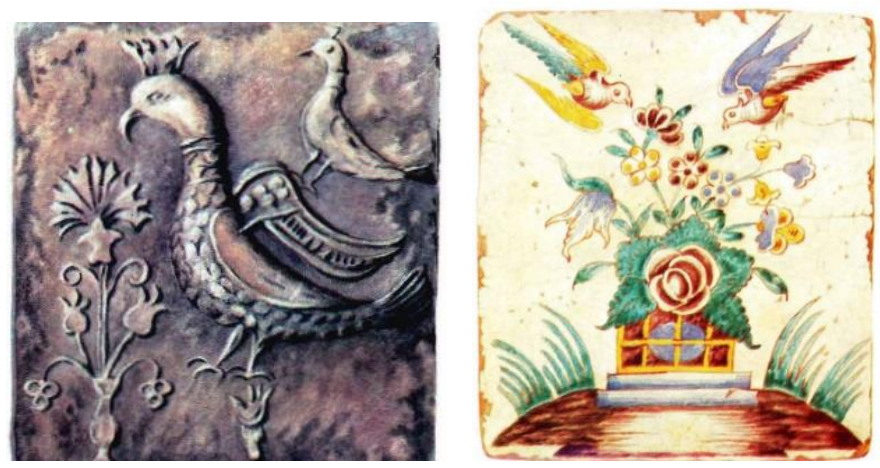

Фиг. 13. Маслих, Руско керамично изкуство
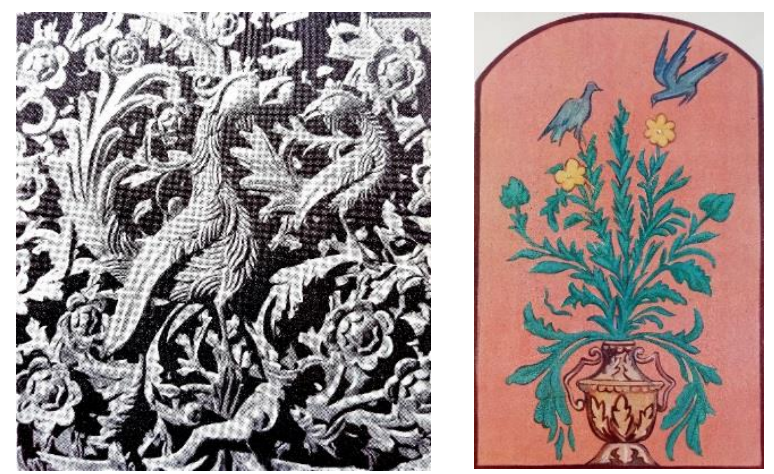

Фиг. 14. Фрагмент от иконостаса на църквата „Св. Марина“, Пловаив

Фиг. 15. Стенопис в църквата „Усп. БогороАично“, С.РъЖАавица, КюстенАИАско

Цуциев разказва, че жителите на Осетия „вярвали в съществуването на свещени всезнаещи птици Семург и Бидуирг. Семург гледал в бълещето, а Билуирг - в миналото". Затова Авете птици често се изобразявали като гледащи в Аве противоположни посоки, „понякога със съединени гърбове" (Tsutsiev, 2015: р. 52). Цуциев счита, че именно това изображение със символно значение има хералдическа стойност и се явява пьрвооснова на много гербове по света. В случая „ролята на централен, определящ елемент на композицията има Аьрвото на живота", което в следващи визуални проекти се изразява понякога с части от това Аърво - клонка, цвят, плоА. СпореА Цагараев често централен елемент на композицията е свещенна ябълка, 
Символизираща Световното дьрво или Аьрвото на живота, като се обрьща внимание на апотропейния смисьл на ябълката като Ааряваща живот, грижа, знание и като цяло - вьп^ащаваща символа на съзиланието и развитието (Tsagaraev, 2000: р. 28).
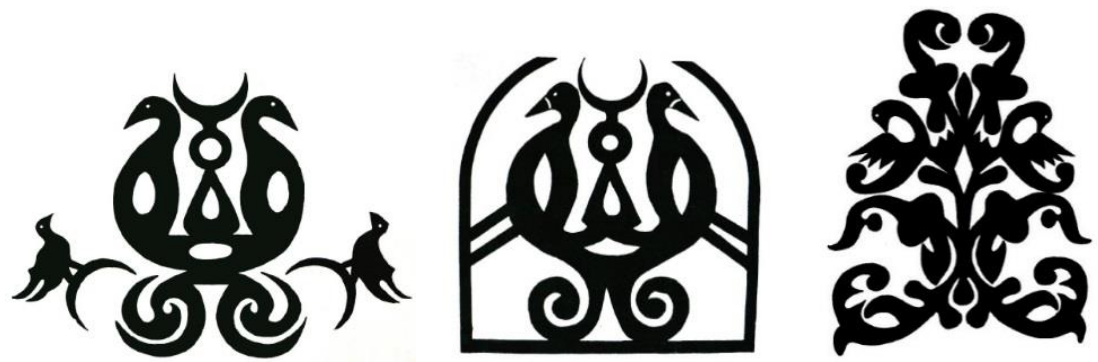

Фиг. 16. Орнаменти от Северна Осетия (Tsutsiev, 2015)
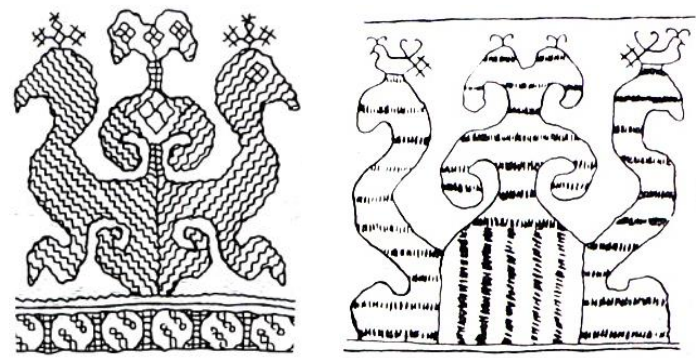

Фиг. 17. Орнамент от връхна ареха, 19 в., Новгород,

(Tsutsiev, 2015: pp. 102, 103)
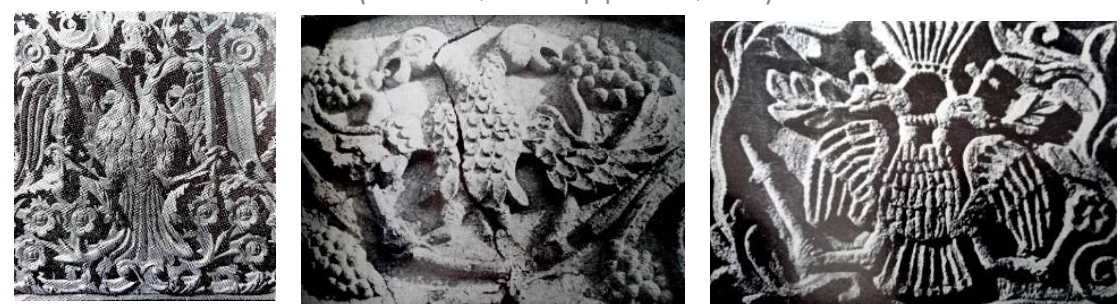

Фиг. 18. Фрагмент от иконостаса на църквата „Св. Марина“, П^овАив Фиг. 19. Каменорезбена украса на врата в църква в с.Аивля, Пернишко

Фиг. 20. Изображение на Авуглав орел в църквата „Св.Архангел Михаи^“ в С.СтуАена, Пернишко 

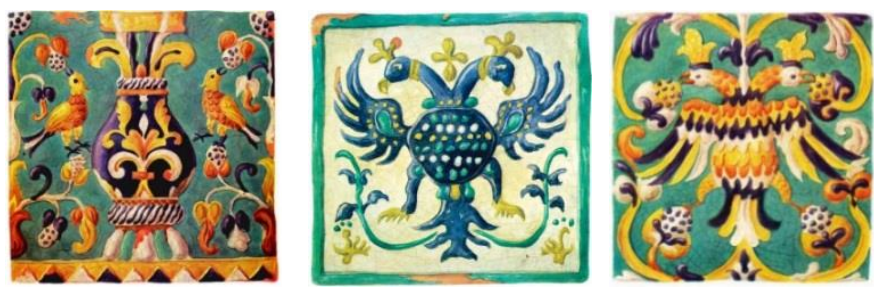

Фиг. 21. Маслих, Руско керамично изкуство

В руските легенАи присьстват птиците Сирин и Алконост. Сирин е тъжна птица, а А^коност - весела. А^коност прелита наА овошките през пролетта и от крилете й струи сила за п^одните Арьвчета. Сирин и А^коност се изобразяват с грьб еАна към Аруга поА Аьрвото на живота, тъй като те представляват Атете страни на живота - светлина и тъмнина, раАост и скръб.

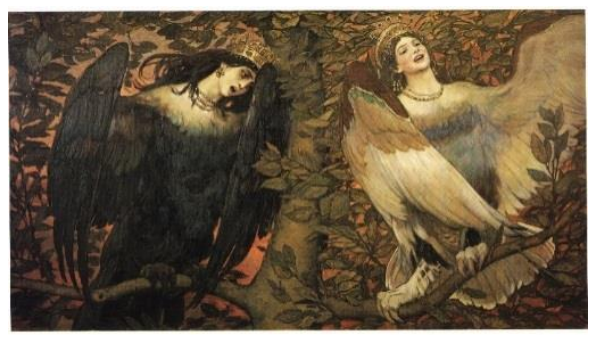

Фиг. 22. Сирин и Алконост, ИАюстрация от руския фолк^ор
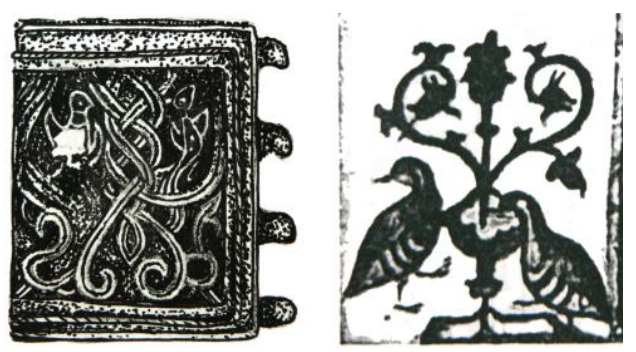

Фиг. 23. Фрагмент от гривна, НовгороА

Фиг. 24. Аекорация на книга, Византия, края на XII в. 
Когато Авете птици глеАат в еАна посока - спореА Цуциев - това знак за еАинен стремеж, еАнакви ценности, символ на Ауши, обеАинени от еАна илея.

Често срещан мотив е Аьрвото на живота с три птици в клоните му. В библейски план, три гъльба се асоциират със Светата Троица (Tsutsiev, 2015: р. 67). Спорел Цигараев три вьлшебни птици „медиатори на свещенното Аьрво“ обозначават три сакрални зони по вертикала - врьх, среАна и ниска част, на които съответстват небесен, земен и полземен светове (Tsagaraev, 2000: р. 32). Цуциев доразвива приказната концепция в съответствие със сюжета за три сестри - три въ^шебни птици при З^атната ябълка, която - както твърАи Цигараев също символизира Аървото на живота, както и знанието. А неговите златни п^одове са грижливо пазени от трите птици-вълшебници фабула, широко застьпена в руските наролни приказки.
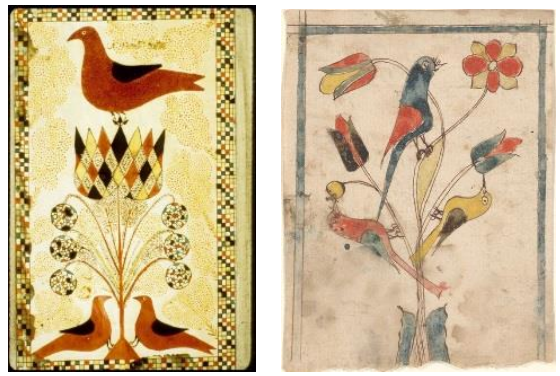

Фиг. 25. Мотиви от инАИански композиции
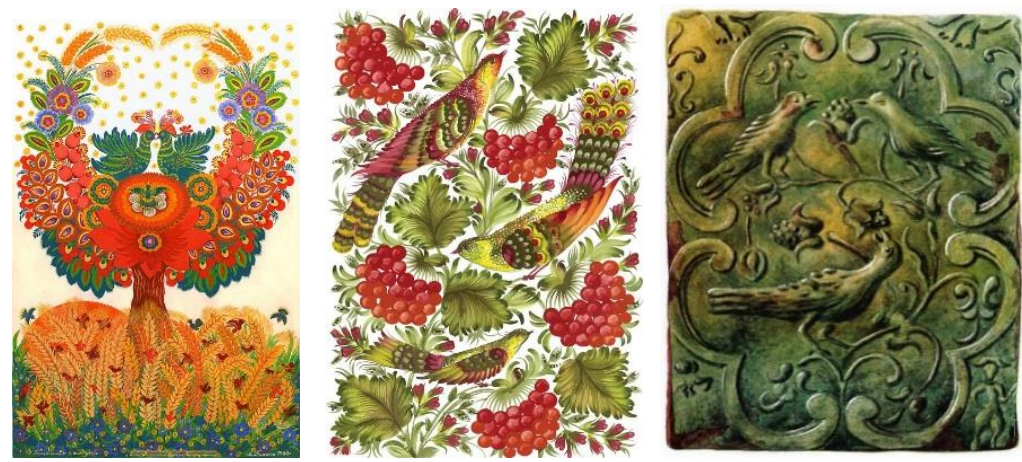

Фиг. 26. Руско Аекоративно и керамично изкуство 
Хансарл ни запознава с илеи от тибетската традиция, поспециално Бьон учението, спореА което винаги в енна съзидателна врьзка межАу Аве Ауши присъства „трети участник“, който преАставлява самата връзка в духовен пан. Съгласно това учение, третата птица има за залача $\Delta$ а се грижи за силата на отношенията межАу Аругите Аве и Аа засилва, подхранва всички резултати, постигнати от кАасическата фрормула „Авойка птици“" (Hansard, 2006: pp. 46-48).

Четири птици на Аьрвото на живота символизират четирите посоки на света. Тази илея присъства в инАийски, мексикански, руски епос (Tokarev, 1980: pр. 402-403). Посочва се наратив, спореА който четири митични същества се намират на Аьрвото на живота и глеАат в четирите посоки. Четири вятьра ^юлеят к^оните на Аьрвото на живота.
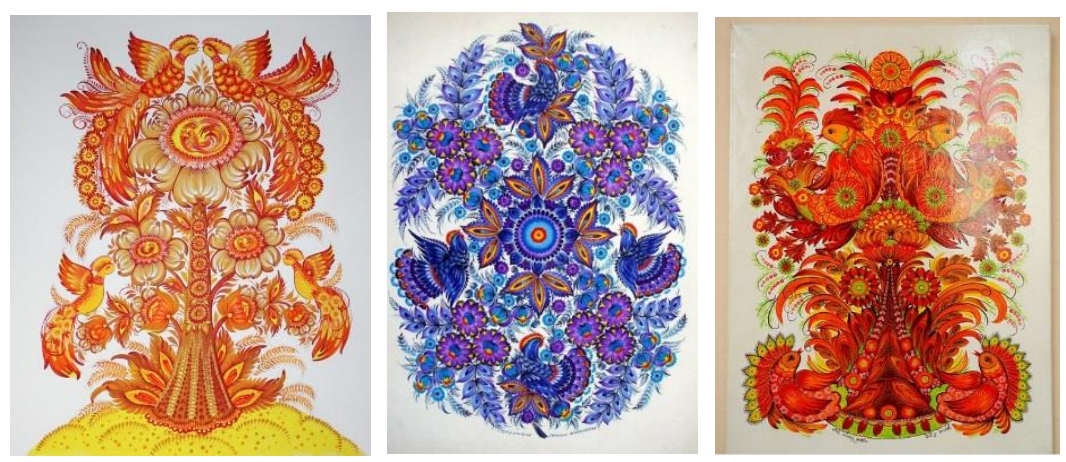

Фиг. 27. Руско Аекоративно изкуство
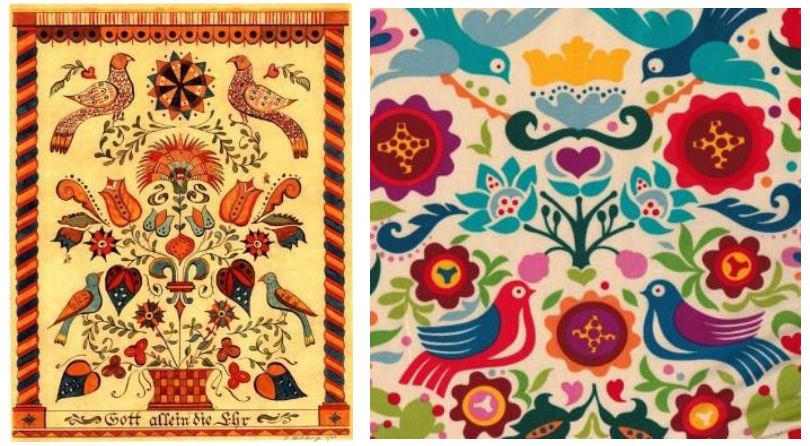

Фиг. 28. Европейски интерпретации 
Често фррагменти от Аьрвото заеАно с птиците се изобразявало в четиристранни розети, които сочат посоките на света. А птиците на тях били съответно 4 или 8.
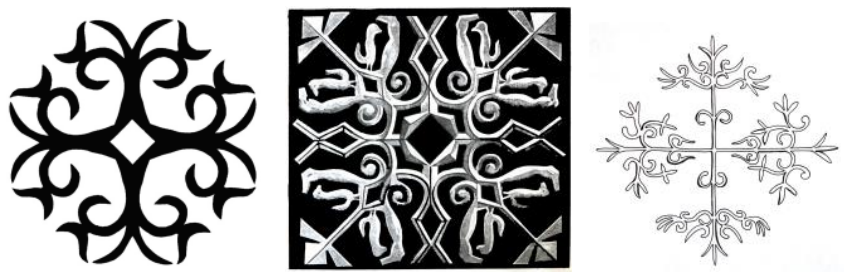

Фиг. 29. Орнаменти от Северна Осетия, 19-20 в. (Tsutsiev, 2015: pp. 89-99)

Така структурирания молел на Аьрвото на живота, ориентирано в четирите посоки, с Аве оси на симетрия, постепенно се е превьрнал в мотив за бродерия и дьрворезба (Tsutsiev, 2015: р. 61). Ажейн Стивенсон разказва за визуален образ на египетско Аьрво на живота с пет птици, които Символизират „належАа, Аюбов, ралост, благополучие и скрьб. Четири от птиците глеАат на изток, т.е. в бъдещето и само еАна на име УАоА - на запал, в миналото“. СпореА същия автор, съществува още енна версия на символиката на нетте птици на Аьрвото на живота, която според него е сходна на пьрвата, а именно: птиците символизират етапи от човешкия живот - Аетство, Юношество, мАаАОст, зря^ост и старост. Пьрвите четири птици отново глеАат „на изток, към Ни^“, а петата - УАОА- „на запаА, към Аолината на мъртвите“. Авторьт продьлжава своя коментар: „Аокато обичаш, надяваш се и вярваш,

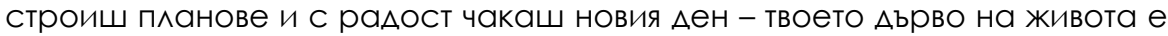
живо, зелено и с пеещи птици... а ако мислиш само за миналото, ти си заселил своето Аърво на живота с птици УАОА, заеАно С тях охкаш И се оп^акваш и твоето Аьрво се превръща в Аьрва ...на тревата в Авора. Интересно е, че в класическите египетски изображения на Аьрво на живота с пет птици, очите на петата птица УАо са нарисувани като човешки, а на останалите птици очите са птичи“" (Stevenson, 2014: pp. 23). Аали се има предвил, че в природата отношението към живота е помьдро, а колкото повече се гледа с очите на хората - отношението е по-незряло, ^ишено понякога от естественото състояние на ралост? 

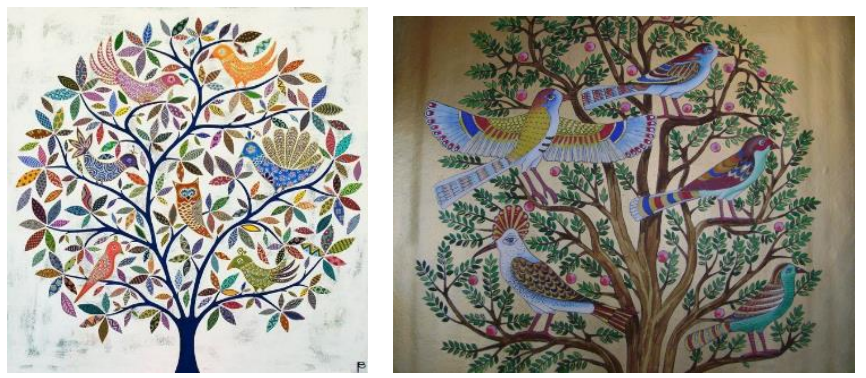

Фиг. 30. Вероника Нелсон, стенопис

Фиг. 31. Египетско Аърво на живота - по материали на Стивънсон

Съществува илеята, че изображение на Аьрвото на живота със седем птици по клоните се рисува в чест на християнския празник Благовещение (Tsutsiev, 2015: p. 73).
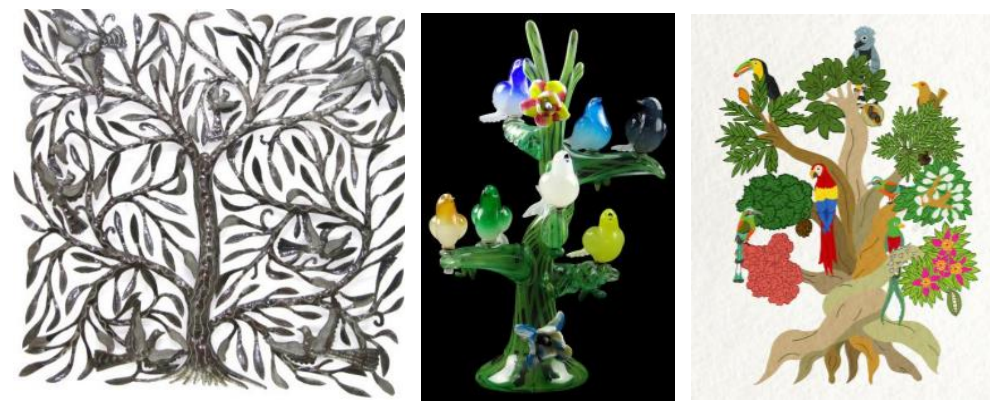

фиг. 32. Металоп^астика от Таити

Фиг. 33. Стъклопластика, Мурано, Италия Фиг. 34. Пано в парк в централна Америка

Какво символизират седемте птици? „Когато Аева Мария е изобразена, заобиколена от селем гьльбици, тя представя Mater sapientiae, майката на мьдростта" (Prior, 1993: р. 40). Селем са Аните от сеАмицата, а сеАмият от тях, неделята е отреАен за почивка на Госпол. Седем са континентите на нашата планета, Седем са основните цветове на дьгата, селем са музикалните тонове, Селем денонощия прольлжава лунната ораза. В руското християнство има традиция на Благовещение $а$ а се пускат на свобола селем Аиви птици. Числото селем е числото на Сътворението. Според Свещеното писание селем е съвьршеното число. То управлява времето и пространството. Вероятно затова селемте птици на Аьрвото на живота, готови Аа излетят, символизират оповестяването на толкова значимо събитие - преАстоящото 
илване на М^аленеца, тяхната песен е в синхрон с Благата вест. В книгата „Откровение" в Новия завет числото 7 се появява често: 7 цьркви, 7 златни свещника, 7 звезди, 7 ^ампи, 7 печата, 7 царе. Не само в Християнството числото седем има тайнствено, мистично значение. В Египет седем е Символ на вечния живот, числото на бог Озирис. В Аревна Гърция селем е Символ на Аполон. Аполон се ролил в селмия ден на месеца, а неговата лира имала седем струни. В ислямската традиция съществуват сеАем невести и селем земи, седем врати на рая и селем стьпала на ала, селем пророци - Алам, Ной, Авраам, Моисей, Аавил, Иисус, МохамеА. Мож би затова в различни части на света можем да намерим визуалния образ на Аьрвото на живота със селем птици по к^оните.
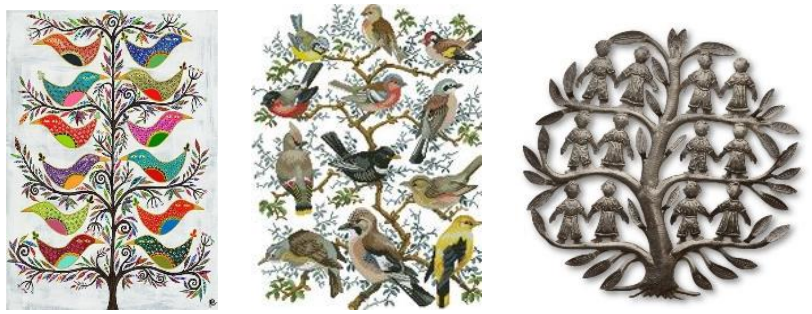

Фиг. 35. Вероника Нелсон, стенопис - Аваналесет ґъъба на клоните на Аьрвото на живота символизират Аваналесетте апостола (Toporov, 2011 : p. 4).

\section{Фиг. 36. Нанси, АонАОн, пано \\ Фиг. 37. Металопластика, Хаити}

В някои случаи се наблюАава антропологизиране на птиците по к^оните на Аьрвото на живота. Може $а$ а се предположи, че Аьрвото с дваналесетте апостола е илеен отзвук от Йесеевото Аърво.
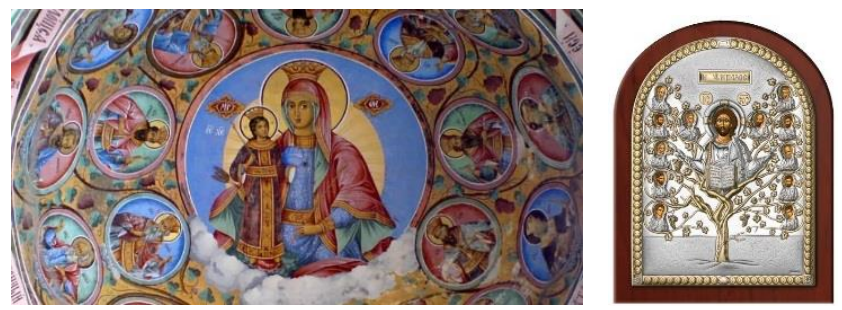

Фиг. 38. Аърво Йесеево в Рилски манастир

Фиг. 39. Аървото на живота - църковна пластика, Италия 


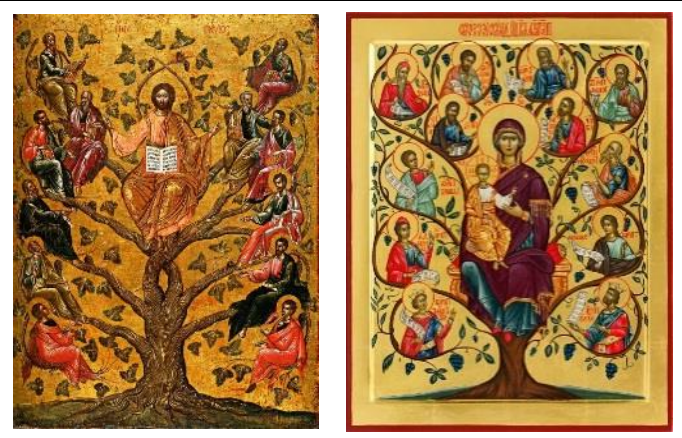

Фиг. 40. Аърво Йесеево в руската иконопис

Аали антропологизирането и Аопьлнителното одухотворяване на

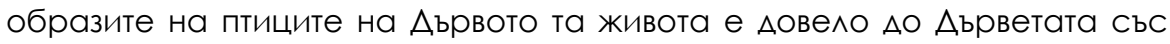
светии и апостоли или образьт на Йесеевото Аьрво е повол за композиране на дьрвета със селем, Аваналесет птици или Аруг брой, свързан с християнски наратив? Предстои $а$ а се проучат образци на християнското и Аекоративно изкуства и $А$ се извеАат евентуални врьзки межлу тях. Естествено, съществуват образи на Аървото на живота с различен от изброените числа птици по клоните. Темата е отворена и преАстоят изслеАвания и систематизация на символиката, носена от броя птици на Аървото в различни жанрове на визуалните изкуства.

Птиците на Аьрвото на живота са различни. СпореА Цуциев, те са "гъльби, орли или абстрактни птици с неопределена порода". Аействително, в повечето случаи птиците са силно стилизирани. Но има и изображения, в които породата на птиците се разпознава и тя носи своя символика. Орельт е символ на победата и на Ауховното познание. „Той се появява за пьрви пьт като воинска емблема у персийците... Но орельт винаги е бил символ и на Божията Аюбов... Орлите били свещени птици" (Prior, 1993: p. 38). Гъ^ъбът - спореА Приор - е символ на ^юбовта. В библейски план - ако птицата е гъльб - тя е символ на спасение и олицетворява Светият Аух (Tsutsiev, 2015: р. 67). „Гьльбицата се свързва с Божията майка... Знаем, че именно гъ^ъбицата донесла на Ной маслинена клонка... Когато Йоан предтеча кръстил Иисус, Аухът слязьл наА него в образа на гълъбица. ... Гьльбицата символизира третото ^ице от християнската троица" (Prior, 1993: р. 40). Свикнали сме и с образа на гъльб като символ на мира. 
„Кукумявката, емблема на Атина Палала, е птицата на мьдростта. В Тибет тя символизирала ученика, усамотен в духовното си уединение" (Prior, 1993: p. 42).
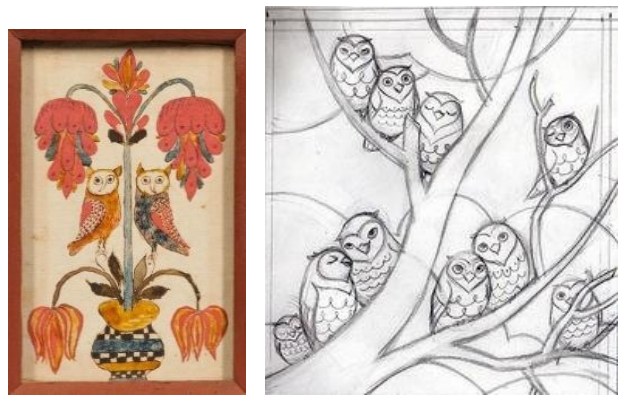

Фиг. 41. Аървета на знанието със сови по к^оните в руското Аекоративно изкуство

Пауньт е символ на безсмьртието, защото през есента перата му опадват, а през пролетта му поникват нови...Крьговете, които украсяват опашката на пауна, представляват очите на Аргус, натоварен от Хера Аа пази кравата Ио" (Prior, 1993: p. 45).
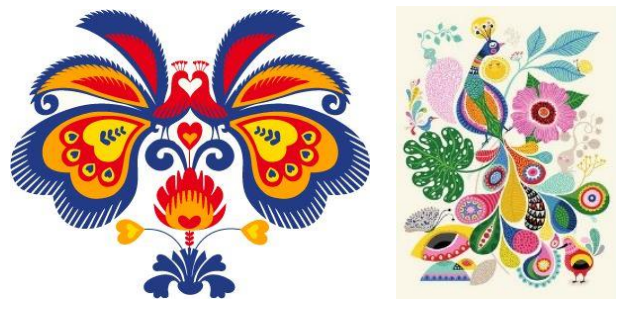

Фиг. 42. Полско и украинско Аекоративно изкуство

СпореА Цуциев „пауните са царски птици, символ на С^ьнцето, на Космоса и изобилието, плодородието и безсмьртието". Следователно, те в още по-голяма степен предвещават и пожелават всички ценни за човечеството блага (Tsutsiev, 2015: р. 66).
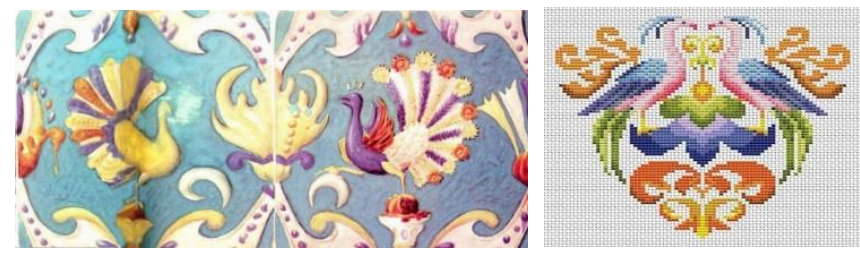

Фиг. 43. Маслих, Руско керамично изкуство Украински мотив, бродерия 

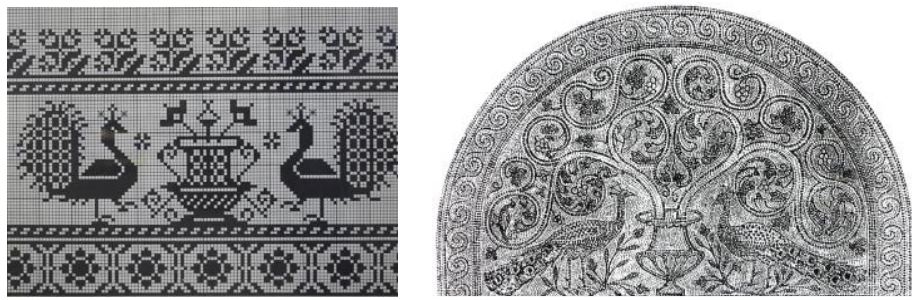

Фиг. 44. Мотив от руска шевица Мозаечен поА в апсидата на базиликата Афентели на о.Аесбос, V-VI в.
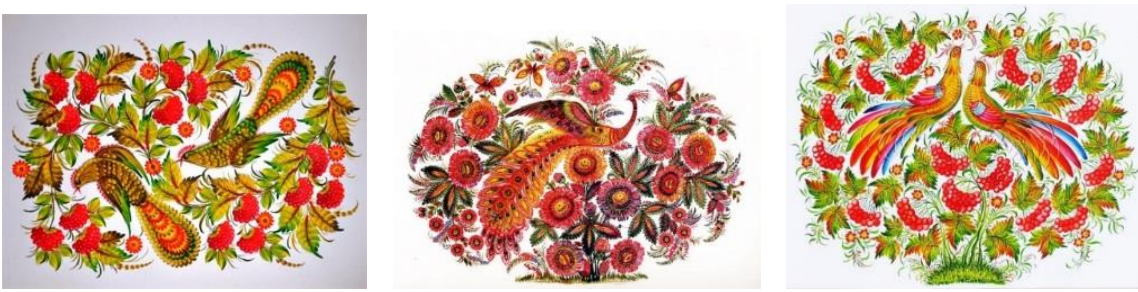

Фиг. 45. Руско народно творчество - палех и хохлома

„От Средновековието насам петельт стои на върха на покрива и на камбанариите като символ на блителността и покровител срещу злите духове. Петельт е сльнчева птица и с песента си прогонвал Аемоните и техните помощници" (Prior, 1993: p. 48).
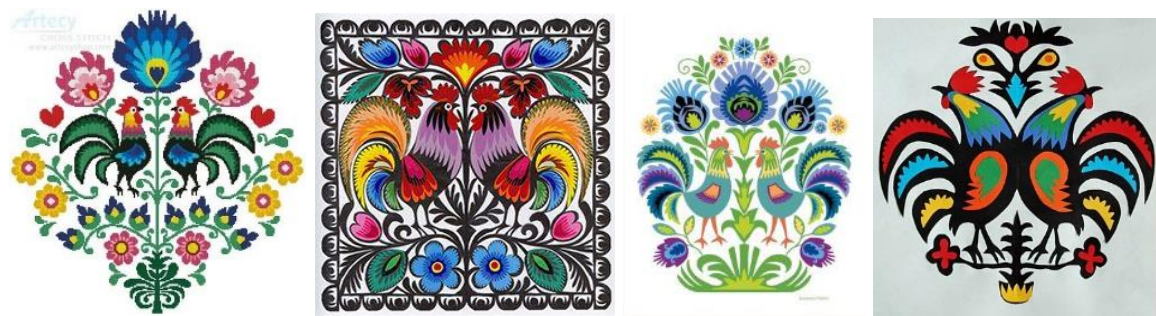

Фиг. 46. Петли в руското и полското Аекоративно изкуство

Естествено, птичият свят е многоброен и е трудно $\Delta$ а се анализира, а и най-вероятно изброените птици имат и Аопьлнителна символика. Направен е кракък преглеА на най-основните значения при изобразяване на образите на птици. Птиците - стилизирани или не, откриваме в културата на много места по света, върху предмети от бита: 

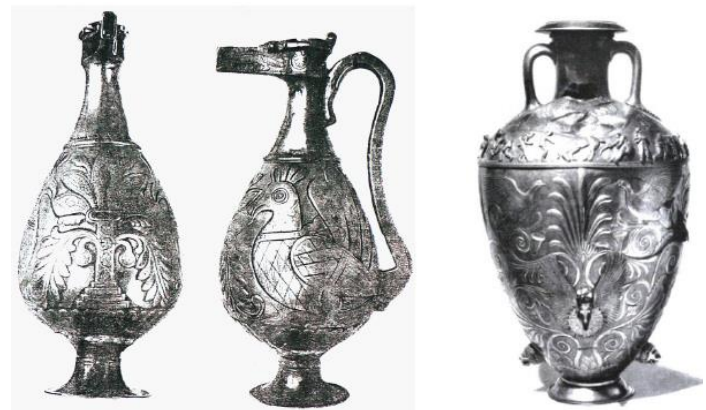

Фиг. 47. СъАове с изображения на птици при Аървото на живота от Аагестан и Украйна (Tsutsiev, 2015)
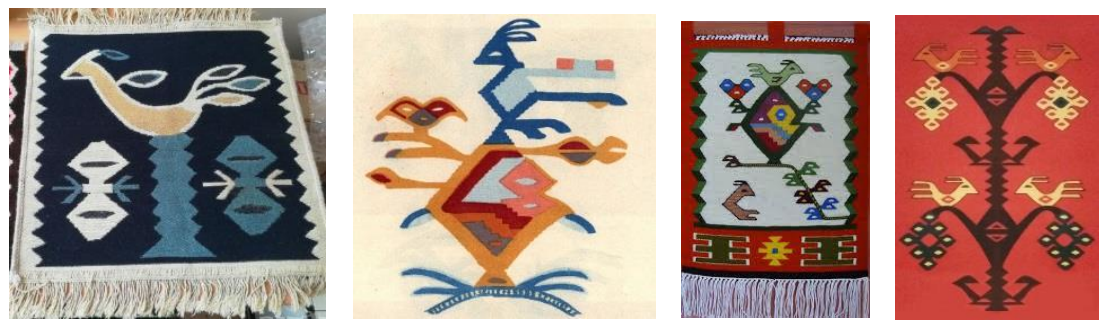

Фиг. 48. Чипровски килими със стимизирани мотиви на птици върху

\section{Аървото на живота}

Това е само елна малка част от творчеството на знайни и незнайни майстори и художници, които са изразили визуално своето усещане за присъствието на птиците върху Аьрвото на живота.

Темата за птиците на Аьрвото на живота е много интересна за учениците в часовете по изобразително изкуство и компютьрна графика в средното училище. Подходяща е за разработване, тъй като стимулира силно въображението, както и символното и абстрактното възприятие и мислене на учениците. Някои от ученическите творби са следните:
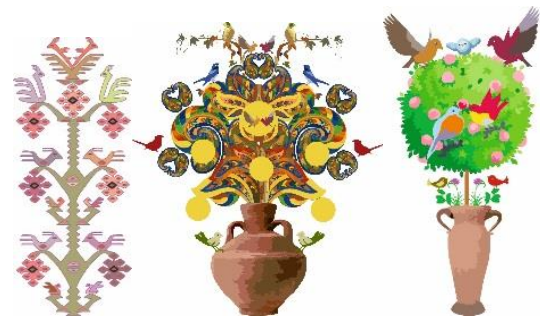

THE IMAGE OF THE BIRD ON THE TREE OF LIFE - 

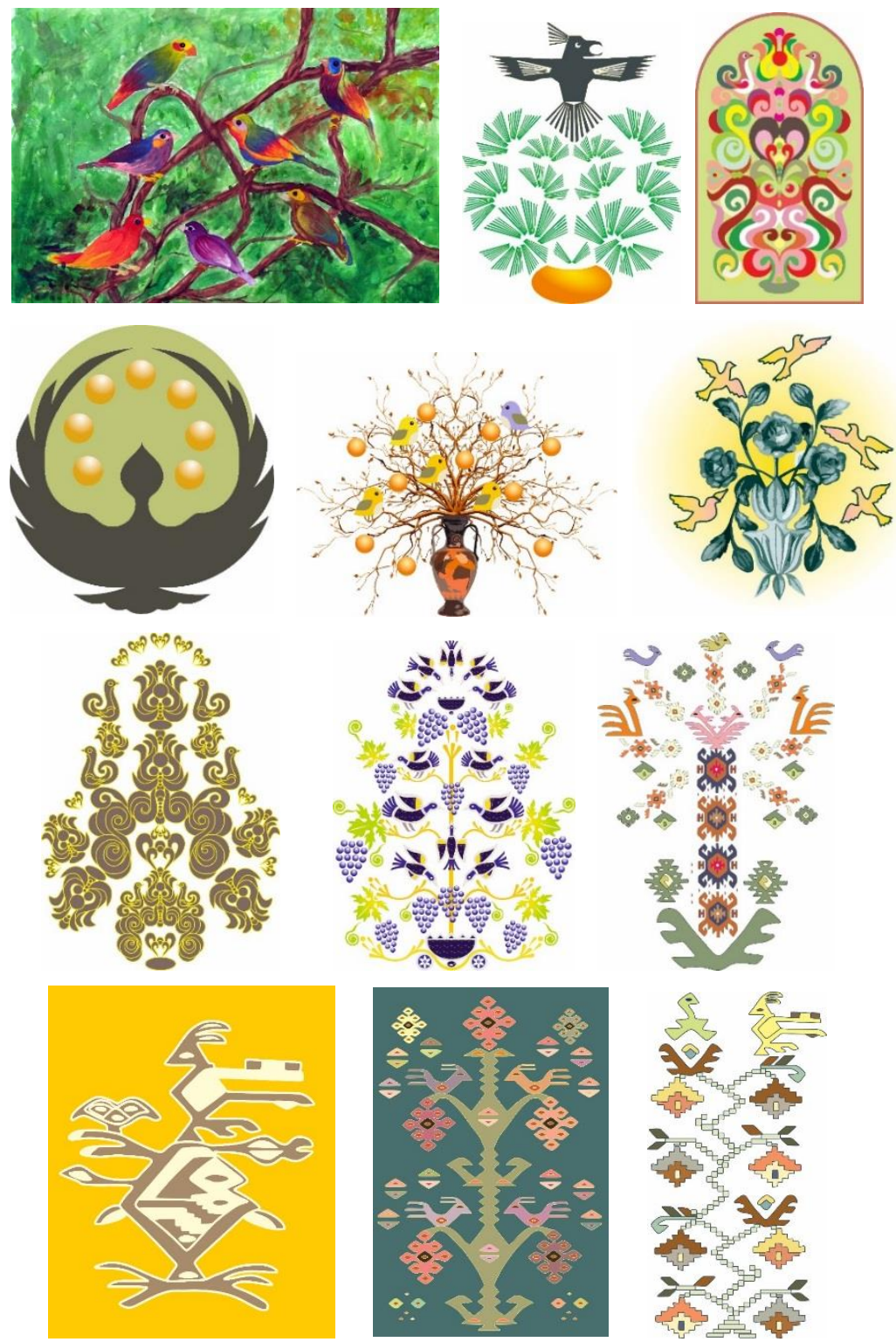

Фиг. 49. Ученически творби

Темата за птиците на Аьрвото на живота е неизчерпаема и Аава възможност на всеки учител да я развие творчески. Често самите 
ученици откриват интересни оракти от историята и културата на народите, свързани с птичето присъствие на Аьрвото на живота. А творческото пресъздаване на композиции по темата способства както за обогатяване на символната култура на учениците, така и за развитие на знания и умения по предметите изобразително изкуство и компютьрна графика.

\section{Online Resources (Интернет източници)}

Stevenson, J. (2014). Tree of Life, 2014 (In Bulgarian: Стивенсон, Аж. Аьрвото на живота, 2014, [https://janesevenstones.livejournal.com/423135.html, (Last view: 20.09.2019)]

Toporov, V. (2011). Tree of Life - a symbol of peace, 2011 (In Russian: Toпоров, B. Арево Жизни-символ мироустройства, 2011), [http://www.shield-ofculture.org/viewtopic.php?t=286, (Last view: 20.09.2019)]

\section{AИTEPATYPA / REFERENCES}

Engels, F. (1978). Anti-During, Thought, Moscow, 1978. (In Russian) / [Енге^с, Ф., Анти-Аюринг, Мысль, Москва, 1978.]

Hansard, K. (2006). The Tibetan Art of Positive Thinking, Hermes, Plovdiv, 2006. (In Bulgarian) / [Хансарл, К, Тибетското изкуство на позитивното мислене, Хермес, ПАовАив, 2006.]

Heinrich, A. (1995). Early medieval catacomb burial grounds in the villages of Chmi and Koban (based on the materials of the Vienna Museum of Natural History), Alana: History and Culture. Alanica - III. Vladikavkaz, 1995. (In Russian) / [Хайнрих А. Раннесредневековые катакомбные могильники у селений Чми и Кобан (по материалам Венского естественно-исторического музея), А^аны: история и культура. Alanica - III. В^аликавказ, 1995.

Kuzmina, E. E. (1976). On the semantics of images on the Chertomlytsky vase, Soviet archeology. 1976, No. 3. (In Russian) / [Кузьмина Е. Е. О семантике изображений на чертомлыцкой вазе, Советская археология. 1976, № 3.]

Machinsky, D. A. (1978). The Pectoral of Tolstoy's Tomb and the Great Female Deities of Scythia, Culture of the East. Antiquity and the early Middle Ages. L., 1978. (In Russian) / [Мачинский А. А. Пектораль из Толстой Могилы и великие женские божества Скифиии, Культура Востока. Аревность и раннее средневековье. А., 1978.] 
Maslova, G. S. (1978). The ornament of Russian folk embroidery as a historical and ethnographic source. М., 1978. (In Russian) / [Маслова Г. С. Орнамент русской народной вышивки как историко-этнографический источник. М., 1978.]

Prior, J. (1993). Universal Symbols, Gutoranov and Son, Sofia, 1993 (In Bulgarian) / [Приор, Ж. Универсалните символи, Гуторанов и син, София, 1993]

Prop, V. Ya. (1995). Historical Roots of the Magic Tale, ed. Window, Sofia, 1995. (In Bulgarian) / [Проп, В.Я., Исторически корени на вълшебната приказка, изА. Прозорец, Софиия, 1995.]

Tokarev, S. (1980). Myths of the peoples of the world, Encyclopedia, ed. Soviet Encyclopedia, Moscow, 1980. (In Russian) / [Токарев, C, Мифы народов мира, Энцик^опедия, иза. Советская энцик^опедия, Москва, 1980.]

Tsagaraev, V. A. (2000). Golden apple orchard: history, mythology, art, semantics. Vladikavkaz, 2000. (In Russian) / [Цагараев В. А. Золотая яблоня нартов: история, мифология, искусство, семантика. В^аликавказ, 2000.]

Tsutsiev, A. (2015). A pair of birds on the tree of life (Ossetian ornament as historical source): monograph, Vladikavkaz, 2015. (In Russian) / [Цуциев, А. Пара птиц на дереве жизни (Осетинский орнамент как исторический источник): монографрия, В^аликавказ, 2015.] 


\section{КУАТУРНО-ИСТОРИЧЕСКО НАСАЕАСТВО: \\ ОПАЗВАНЕ, ПРЕАСТАВЯНЕ, АИГИТААИЗАЦИЯ}

\section{CULTURAL AND \\ HISTORICAL \\ HERITAGE}

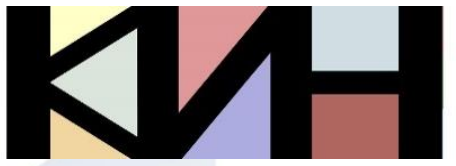

PRESERVATION PRESENTATION DIGITIZATION

\section{Съставители \\ Галина БогАанова Ваня Матеева}

Материалите в сборника са обект на авторско право. Разрешава се безвъзмезАното ползване на техни електронни/ хартиени копия само за лична употреба или обучение, при пьлно цитиране на текущата страница и слеА писмена Аекларация от цитиращия за Аипса на тьрговски намерения. За копиране поА Аруга фрорма, препубликуване или публикуване на сървьри се изисква писмено разрешение и/или заплащане.

() Авторски колектив, 2019 Технически реАактори: Николай Ноев Калина Сотирова-Вълкова Ка^оян Николов

\section{Editors}

Galina Bogdanova Vanya Mateeva

This work is subject to copyright. Open and free of charge use of digital/hard copies of publications is granted only for personal or educational use, with full citation of the current page, and after written declaration of the quoting side for not-commercial Intention. For any other reproducing types, republishing, photocopying, recording, or any other storage retrieval system/ server written permission and/or fee is required.

() Authors` Group, 2019

Technical editors:

Nikolay Noev

Kalina Sotirova-Valkova

Kaloyan Nikolov

\section{Научна поредица: том 5, брой 2 (7)/2019}

Science series: vol. 5 , issue $2(7) / 2019$

www.math.bas.bg/vt/kin

ISSN: 2367-8038 